\title{
Agranulocytosis associated with carbamazepine, and a positive reaction with anti-lymphoid leukaemia antiserum during recovery
}

\author{
C. W. I. OWENS \\ B.Sc., Ph.D., M.B., M.R.C.P. \\ N. E. PARKer \\ M.B., M.R.C.P. \\ P. P. NunN \\ B.A., M.B. \\ J. DAVIES \\ M.B., M.R.C.P. \\ University College Hospital Medical School, Department of Medicine, Rayne Institute, \\ University Street, London WC1E 6JJ
}

\begin{abstract}
Summary
Carbamazepine is a valuable drug in the treatment of trigeminal neuralgia and temporal lobe epilepsy. Rarely agranulocytosis has been described associated with its use but in this further non-fatal case a new finding of a positive reaction with anti-lymphoid leukaemia anti-serum was seen during the recovery phase.
\end{abstract}

A brief review of 18 cases in the literature is provided and it is noted that $94 \%$ of reported cases are over the age of $\mathbf{4 5}$ years. The significance of the haematological finding is discussed.

\section{Introduction}

Carbamazepine (5 carbamyl-5H-dibenzazepine) was first used in Europe as an anti-convulsant in 1960. It is an iminostilbene and related to imipramine. By 1963 it had been found, sometimes within hours, to provide relief for between 50 and $90 \%$ (Blom, 1963; Spillane, 1964) of patients, with trigeminal neuralgia, in doses of $200-1600 \mathrm{mg}$ daily. After formal validation it became the treatment of choice (Davis, 1969; Crill, 1973) despite occasional reports of liver dysfunction, cutaneous eruptions and neurological symptoms. Many symptomatic side effects could be minimized by initiating treatment in small doses $(100-200 \mathrm{mg}$ daily) (Spillane, 1964) and, more recently, attention had turned to its use in other indications such as temporal lobe and grand mal epilepsy (Livingston et al., 1967; Roberts, 1977).

Despite its undoubted therapeutic value, adverse reactions associated with its use have been noted. Out of 441 such reactions reported in the U.K. since 1964, there have been 11 examples of granulocytopenia, 10 of aplastic anaemia and one each of leucopenia and agranulocytosis (the present case)
(Committee on Safety of Medicines, personal communication, 1979). Deaths have occurred (Donaldson and Graham, 1965; Dyer, Hughes and Jenkins, 1966; Saleh and Mendes de Leon, 1968; Fellows, 1969) and collective experience has suggested that withdrawal of the drug may be necessary in up to $19 \%$ of cases treated. However, it should be added that a causative role has not been unequivocally established largely through a paucity of pre-treatment or pre-crisis haematological data (Livingston, Pauli and Pruce, 1978). The authors would like to summarize existing reports and add another case brought to their attention where unusual marrow cell markers were seen during recovery from agranulocytosis.

\section{Case report}

A 61-year-old builder gave a 9-year history of headache originally localized behind the right ear over recent months affecting the whole of the right side of the head. Attacks usually occurred in the mornings, could last up to several hours, were sometimes initiated by draughts and the pain which was non-pulsatile would feel superficial extending from behind the right ear to above the right eye. There was no family history of migrane other than in the wife and daughter. There was no history of scalp tenderness, photophobia, hyperaesthesia, fortification figures or vomiting and therapeutic trials of cafergot, clonidine and paracetamol had failed. Although the cervical spine showed some degenerative changes radiologically, it appeared normal to clinical examination and the pain was unaffected by manipulation.

Carbamazepine was introduced gradually to a dose of $200 \mathrm{mg} 3 \mathrm{times/day,} \mathrm{and} \mathrm{the} \mathrm{pain} \mathrm{resolved,}$ but within 4 weeks there was persistent cough 
followed 2 weeks later by malaise, fever and oral candidiasis. The dose was reduced but symptoms persisted and, following default from out-patient follow-up, the patient was admitted urgently and found to be severely ill and suffering from toxic confusion, malaise and a sore throat. Apart from oral candidiasis and fever $\left(39.5^{\circ} \mathrm{C}\right)$ there were no abnormal physical findings.

\section{Laboratory investigations}

The WCC immediately before treatment was $9.6 \times 10^{9} / 1$. After 48 days of treatment it was found to be $1.3 \times 10^{9} / 1(0 \%$ neutrophils, $97 \%$ lymphocytes, $2 \%$ monocytes), $\mathrm{Hb} 12.8 \mathrm{~g} / \mathrm{dl}$, red cell count $4.48 \times 10^{12} / 1$, platelets $196 \times 10^{9} / 1$ and ESR $45 \mathrm{~mm} / \mathrm{hr}$. Liver function tests were normal. Marrow aspirated from the posterior iliac crest at presentation was extremely hypocellular and a severely depressed myelopoiesis was represented by only occasional myeloblasts and promyelocytes. The myeloid: erythroid (M:E) ratio was $1: 10$. A second marrow aspirated 2 days after admission was still hypocellular but myelopoiesis was recovering with a $\mathrm{M}: \mathrm{E}$ ratio of $1: 1$ and some myelocytes present; there were $24 \%$ lymphoid cells. This marrow was sent for membrane immunological tests and $20 \%$ of the cells present were found to react positively with anti-acute lymphoid leukaemia anti-serum (Anti-ALL). Clinical recovery was rapid and the last marrow tested 4 weeks after presentation was within normal limits. Morphologically, there was no excess of blast cells and immunological studies with anti-ALL antisera were negative.

Active treatment included 2 white cell transfusions, daily doses of prednisolone $30 \mathrm{mg}$, fluoxymesterone $10 \mathrm{mg}$, ampicillin $1 \mathrm{~g}$, and amphotericin lozenges sucked continuously. Six days after discontinuing carbamazepine a normal differential was established and by 8 days the total WCC rebounded to $27 \times 10^{9} / 1$ with $17 \%$ myelocytes in the circulating blood. Two weeks later both total count and differential were normal, the patient having been discharged. Within 6 weeks the headaches had returned.

\section{Discussion}

Although the pharmacology and side effects of carbamazepine have been reviewed (Livingston et al., 1967; Crill, 1973), a mechanism leading to agranulocytosis is not described. It can occur after different periods of exposure, is unpredictable, not clearly related to the total dose consumed (Table 1) and appears to be an idiosyncratic response. However, statistical analysis (Sign test) (Killain, 1969) and observations in other series (Killain and Fromm, 1968; Al-Ubaidy and Nally, 1976) reveal significant leucopenia in the early weeks of treatment. Other reports include, dose-related leucopenia (Davis, 1969; Al-Ubaidy and Nally, 1976) and a chronic leucopenia $\left(1700-3000\right.$ cells $\left./ \mathrm{mm}^{3}\right)$ which can be reversed even after one year by discontinuation or reduction of the dose (Killain, 1969). These features raise the alternative possibility of direct toxicity; however, occasionally (Killaing 1969) a mild leucopenia has resolved spontaneouslis without withdrawal of the drug.

In the severe reactions, some evidence suggests an immunologically based reaction in that they have occurred after previous exposure to the drug or in association with diphenylhydantoin sensitivity. Post-mortem findings also include thymic enlargement (Donaldson and Graham, 1965) and a transient eosinophilia has been reported in $24 \%$ of 71 cases

TABLE 1. Leucopenia reported in association with carbamazepine treatment

\begin{tabular}{|c|c|c|c|c|c|c|c|c|c|}
\hline $\begin{array}{c}\text { Age } \\
\text { (years) }\end{array}$ & Sex & $\begin{array}{l}\text { Average } \\
\text { daily dose } \\
\text { (mg) }\end{array}$ & $\begin{array}{c}\text { Total } \\
\text { exposure } \\
\text { (weeks) }\end{array}$ & $\begin{array}{l}\text { Estimated } \\
\text { total } \\
\text { intake }(g)\end{array}$ & $\begin{array}{l}\text { White cell } \\
\text { count } \\
\left(\times 10^{9} / 1\right)\end{array}$ & $\begin{array}{c}\text { Neutrophils } \\
(\%)\end{array}$ & $\begin{array}{l}\text { Platelets } \\
\left(\times 10^{9} / \mathrm{l}\right)\end{array}$ & Rash & Source \\
\hline 69 & $\mathrm{~F}$ & $400-800$ & 40 & 140 & $3 \cdot 1 *$ & 9 & $<5$ & Yes & \\
\hline 52 & $\mathbf{F}$ & $300-1200$ & 20 & 150 & $1 \cdot 2^{*}$ & $33 \cdot 5$ & $<10$ & No & Donaldson and Graham, 1965 \\
\hline 5 cases & & $600-800$ & 2 & 10 & $4 \cdot 0$ & & & No & \\
\hline 1 case & & $600-800$ & 21 & 100 & $4 \cdot 0$ & & & No & Graham, 1965 \\
\hline 48 & $\mathbf{F}$ & $600-800$ & 39 & 180 & $1 \cdot 9^{*}$ & 39 & $<10$ & No & Dyer et al., 1966 \\
\hline 2 cases & & Between & 4 & - & $2 \cdot 5$ & & & - & Livingston et al., 1967 \\
\hline 1 case & & 300 and 200 & 52 & - & $3 \cdot 2$ & & & - & Livingston et al., $196 /$ \\
\hline 45 & $\mathrm{~F}$ & 800 & 44 & 90 & $0 \cdot \overline{8}$ & 4 & $6 \cdot 1$ & - & Saleh and Mendes de Leon, 1968 \\
\hline \multirow[t]{3}{*}{49} & $\mathbf{M} \dagger$ & $200-600$ & $16+7$ & 100 & $1 \cdot 2 *$ & & 15 & No & Fellows, 1969 \\
\hline & $F \ddagger$ & 600 & 3 & 12 & $3 \cdot 8$ & & & No & n, 1969 \\
\hline & $\mathrm{F} \S$ & 700 & $1 \cdot 4$ & 7 & $3 \cdot 3$ & & 76 & Yes & $n_{1}$ \\
\hline 47 & $\mathbf{M}$ & 600 & 8 & 32 & $2 \cdot 5$ & & & No & Al-Ubaidy et al., 1976 \\
\hline 11 & $\mathrm{~F}$ & 550 & 6 & 23 & $1 \cdot 3$ & $\mathbf{0}$ & 300 & Yes & Prieur et al., 1973 \\
\hline 61 & $\mathbf{M}$ & 600 & 8 & 25 & $1 \cdot 1^{*}$ & 0 & 146 & No & Present case \\
\hline
\end{tabular}

* Hypoplastic marrow.

$\dagger$ Two courses of treatment.

$\ddagger$ Dose related agranulocytosis.

$\S$ Diphenylhydantoin allergy. 
(Davis, 1969). Skin rashes are frequent and the onset of agranulocytosis can be abrupt and progress even after withdrawal of the drug. Incidentally, neither this patient nor one other in the literature exhibited antileucocyte antibodies.

Age may be significant for, although early thoughts related toxicity to total dosage consumed, the mean total dose used in an epileptic series was $363 \mathrm{~g}$ (Livingston et al., 1967) and more than the $180 \mathrm{~g}$ consumed in fatal cases (Donaldson and Graham, 1965; Dyer et al., 1966) treated for trigeminal neuralgia. The mean age in 2 populations being treated for trigeminal neuralgia (the group tending to have most of the serious complications was $>60$ years (Donaldson and Graham, 1965; Davis, 1969) as opposed to 18.2 years for the epileptic population (Livingston et al., 1967) in which significant haematological problems were not recorded. Similarly, no difficulties have been encountered amongst 61 children being treated for epilepsy for between one and 5 years (Rutman, 1977). Unfortunately, the total number of patients exposed to the drug in these 2 age groups is unknown.

The finding of ALL-positive cells has not previously been reported in this situation. There was no morphological evidence of acute lymphoblastic leukaemia and the ALL-positive cells disappeared as the patient recovered. The authors assume that the ALL antigen was present on the 'lymphoid' populations of cells which were reported to be present $(24 \%)$ in the marrow. Cells which are morphologically similar to lymphocytes have been shown to bear the ALL antigen (Greaves et al., 1979).

Anti-ALL serum is raised in rabbits against viable lymphoblasts (Greaves et al., 1975). This serum also reacts with cells from patients suffering a lymphoid blast crisis in chronic myeloid leukaemia (Janossy, Roberts and Greaves, 1976). The anti-ALL serum was originally designed as a leukaemiaspecific probe but cells which react with anti-ALL serum are regularly found in fetal tissues (Greaves et al., 1978), in the marrows of patients recovering from chemotherapy and in the present case in a marrow recovering from drug-induced neutropenia. Thus there is the increasing evidence that the ALL antigen is not a leukaemia-specific antigen and that an immunologically similar antigen is present in a normal population of cells (Greaves et al., 1980). It seems that, normally, the population of ALLpositive cells present is very small but, as happened in this case, they can proliferate after severe marrow damage. It is unfortunate that the first marrow was not studied immunologically since it is not known whether stem cells were profilerating in the presence of the carbamazepine or whether their division was also suppressed so that what was seen was early regeneration once the drug was withdrawn. It is of interest to know precisely at what level of differentiation carbamazepine exerts its influence.

No antibodies to leucocytes were detected in this patient and the marrow supressant action of carbamazepine may not necessarily be immunologically mediated. However, one hypothesis is that antibodies are directed against surface antigens such as the ALL antigen, which is apparently lost during differentiation. It would be of value to look early for antibodies to stem cells or acute lymphoblastic leukaemia cells in the serum of patients suffering similar agranulocytic episodes.

It seems reasonable to exercise great care in giving carbamazepine to patients with known allergy to imipramine or other anticonvulsants (Erslev and Wintrobe, 1962), to those who have initial total WCC of $\left\langle 4.0 \times 10^{9} / 1\right.$ and to the elderly. White cells and platelet counts are indicated fortnightly up to 6 weeks and then monthly and 2monthly for probably up to one year or at least until $200 \mathrm{~g}$ have been ingested. Malaise, mucosal ulceration, bruising and infection are indications for haematological assessment and the onset of rash should also prompt withdrawal of the drug if at all possible.

Should marrow suppression with carbamazepine occur, albeit rarely, then the first step in treatment is withdrawal of the drug with, if necessary, supportive treatment with antibiotics and neutrophil infusions if life-threatening infection supervenes.

\section{Acknowledgments}

We wish to thank Professor O. M. Wrong and Dr A. H. Goldstone for permission to report this case and Dr $M$. Greaves for membrane immunological studies.

\section{References}

Al-Ubaidy, S.S. \& Nally, F.F. (1976) Adverse reactions to carbamazepine (Tegretol). British Journal of Oral Surgery, 13, 289.

BLom, S. (1963) Tic douloureux treated with a new anticonvulsant: experiments with G 32833. Archives of Neurology, 9, 285.

CRILL, W.E. (1973) Carbamazepine. Annals of Internal Medicine, 79, 844.

DAvis, E.H. (1969) Clinical trials of Tegretol in trigeminal neuralgia. Headache, 9, 77.

Donaldson, C.W.K. \& Graham, J.G. (1965) Aplastic anaemia following the administration of Tegretol. British Journal of Clinical Practice, 19, 699.

Dyer, N.H., Hughes, D.T.D. \& Jenkins, G.C. (1966) Hypoplastic anaemia following treatment with carbamazepine. Clinical Trials, 3, 521.

Erslev, A.J. \& Wintrobe, M.M. (1962) Detection and prevention of drug-induced blood dyscrasias. Journal of the American Association, 181, 114.

Fellows, W.R. (1969) A case of aplastic anaemia and pancytopenia with Tegretol therapy. Headache, 9, 58.

Greaves, M.F., Brown, G., Rapson, N.T. \& Lister, T.A. 
(1975) Antisera to acute lymphoblastic leukaemia cells. Clinical Immunology and Immunopathology, 4, 67.

Greaves, M.F., Delia, D., Janossy, G., Rapson, N.T., Chessells, J., Woods, M. \& Prentice, G. (1980) Acute lymphoblastic leukaemia associated antigen. IV Expression on non-leukaemic 'lymphoid' cells. Leukaemia Research, 4, 15.

Greaves, M.F., Janossy, G., Francis, G. \& Minowada, J. (1978) Membrane phenotypes of human leukemic cells: Clinical correlates and biological implications. In: Differentiation of Normal and Neoplastic Hematopoietic Cells. Cold Spring Harbor Laboratory, New York, 823.

Janossy, G., RoberTs, M. \& Greaves, M.F. (1976) Target cell in chronic myeloid leukaemia and its relationship to acute lymphoid leukaemia. Lancet, ii, 1058.

KILLAIN, J.M. (1969) Tegretol in trigeminal neuralgia with special reference to haematopoietic side effects. Headache, 9, 58.

Killain, J.M. \& FromM, G.H. (1968) Carbamazepine (Tegretol) in the treatment of neuralgia: use and side effects. Archives of Neurology, 19, 129.
Livingston, S., Pauli, L.L. \& Pruce, I. (1978) No proven $\$ relationship of carbamazepine therapy to blood dys- $\stackrel{\curvearrowright}{\varnothing}$ crasias. (Letter) Neurology, 28, 101.

Livingston, S., Villamater, C., Sakata, Y. \& Pauli, L.L. (1967) Use of carbamazepine in epilepsy. Journal of the American Medical Association, 200, 204.

Prieur, A.M., Le Bouar, Y., Griscelli, C. \& MozziconaCCI, P. (1973) Carbamazepine agranulocytosis. $\overline{\bar{c}}$ Annales de Pédiatrie, 20, 809.

ROBERTS, F.D. (1977) Tegretol in epilepsy: Proceedings of $\mathbb{D}$ an International Meeting, St Peter Port, Guernsey. Ciba- i Geigy Pharmaceuticals, Horsham.

RUTMAN, J.Y. (1977) Effect of carbamazepine on blood $\overrightarrow{0}$ elements. Annals of Neurology, 3, 373.

Saleh, A.E.C. \& MEndes DE LeON, D.E. (1968) Pancytopenie $\vec{\omega}$ met dodelijke afloop tijdens behandeling met carbamazepine (Tegretol). Nederlands Tiidschrift voor Geneeskunde, 112, 2089.

S PILlANE, J.D. (1964) The treatment of trigeminal neuralgia. Practitioner, 192, 71. 